\title{
(2) OPEN ACCESS \\ Pain management after open liver resection: Procedure-Specific Postoperative Pain Management (PROSPECT) recommendations
}

\author{
Audrey Dieu (1) , ${ }^{1}$ Philippe Huynen, ${ }^{2}$ Patricia Lavand'homme, ${ }^{1}$ Hélène Beloeil, ${ }^{3}$ \\ Stephan M. Freys, ${ }^{4}$ Esther M Pogatzki-Zahn, ${ }^{5}$ Girish P. Joshi, ${ }^{6}$ Marc Van de Velde, ${ }^{2,7}$ On \\ behalf of the PROSPECT Working Group of the European Society of Regional \\ Anaesthesia and Pain Therapy (ESRA)
}

- Additional material is published online only. To view, please visit the journal online (http://dx.doi.org/10.1136/ rapm-2020-101933).

For numbered affiliations see end of article.

\section{Correspondence to} Dr Audrey Dieu, Department of Anesthesiology, Cliniques universitaires Saint-Luc, Bruxelles B-1200, Belgium; audrey.dieu@uclouvain.be

$\mathrm{AD}$ and $\mathrm{PH}$ contributed equally.

$A D$ and $P H$ are joint first authors.

Received 21 July 2020 Revised 20 November 2020 Accepted 22 December 2020 Published Online First 12 January 2021
Check for updates

(C) American Society of Regional Anesthesia \& Pain Medicine 2021. Re-use permitted under CC BY-NC. No commercial re-use. Published by BMJ.

To cite: Dieu A, Huynen $P_{\text {, }}$ Lavand'homme P, et al. Reg Anesth Pain Med 2021:46:433-445

\begin{abstract}
Background and objectives Effective pain control improves postoperative rehabilitation and enhances recovery. The aim of this review was to evaluate the available evidence and to develop recommendations for optimal pain management after open liver resection using Procedure-Specific Postoperative Pain Management (PROSPECT) methodology.

Strategy and selection criteria Randomized controlled trials (RCTs) published in the English language from January 2010 to October 2019 assessing pain after liver resection using analgesic, anesthetic or surgical interventions were identified from MEDLINE, Embase and Cochrane databases.
\end{abstract}

Results Of 121 eligible studies identified, 31 RCTs and 3 systematic reviews met the inclusion criteria. Preoperative and intraoperative interventions that improved postoperative pain relief were non-steroidal anti-inflammatory drugs, continuous thoracic epidural analgesia, and subcostal transversus abdominis plane (TAP) blocks. Limited procedure-specific evidence was found for intravenous dexmedetomidine, intravenous magnesium, intrathecal morphine, quadratus lumborum blocks, paravertebral nerve blocks, continuous local anesthetic wound infiltration and postoperative interpleural local anesthesia. No evidence was found for intravenous lidocaine, ketamine, dexamethasone and gabapentinoids.

Conclusions Based on the results of this review, we suggest an analgesic strategy for open liver resection, including acetaminophen and non-steroidal antiinflammatory drugs, combined with thoracic epidural analgesia or bilateral oblique subcostal TAP blocks. Systemic opioids should be considered as rescue analgesics. Further high-quality RCTs are needed to confirm and clarify the efficacy of the recommended analgesic regimen in the context of an enhanced recovery program.

\section{INTRODUCTION}

Liver resection is increasingly performed on patients with benign tumors, liver metastases and hepatocellular carcinoma. ${ }^{1}$ In addition, living liver donation constitutes an expanding field, given the wellknown organ shortage. ${ }^{2}$ Although variations exist, the most frequent approaches for open liver resection include the use of a right subcostal incision or a reversed L-shaped incision. ${ }^{3}$ Therefore, liver resection irrespective of the approach can be associated with significant postoperative pain. Effective pain control can facilitate early mobilization and reduce postoperative complications. ${ }^{4}$ It has been emphasized that adequate pain management is a key to the success of an enhanced recovery after surgery (ERAS) program in liver resection. ${ }^{15}$

However, the optimal pain management regimen for open liver resection remains controversial. Thoracic epidural analgesia (TEA) has traditionally been used for pain management after major open upper abdominal surgery; however, there are concerns of a coagulopathy after liver resection or intraoperative vascular clamping, preventing its intraoperative use. ${ }^{6}$ Moreover, the emphasis on early postoperative mobilization has reduced its use in recent years. ${ }^{15}$

The Procedure-Specific Postoperative Pain Management (PROSPECT) Working Group is a collaboration of anesthesiologists and surgeons working to formulate procedure-specific recommendations for pain management after surgical procedures. These recommendations are based on procedure-specific literature review. The PROSPECT approach to develop guidelines is unique, such that the available evidence is critically assessed for current clinical relevance. ${ }^{7}$ In addition, the approach reports true clinical effectiveness by balancing the invasiveness of the analgesic interventions and the degree of pain after surgery, as well as balancing their efficacy and adverse effects. ${ }^{7}$

The aim of this review was to evaluate the available literature on the management of pain after open liver resection in adults regardless of the indication. Postoperative pain outcomes defined as pain scores and opioid requirements were the primary focus, but other recovery outcomes, including adverse effects, were also assessed, when reported, and the limitations of the data were reviewed. The ultimate aim was to develop recommendations for pain management after open liver resection.

\section{METHODS}

A review of randomized controlled trials (RCTs) and systematic reviews/meta-analyses published between January 2010 and October 2019 assessing analgesia after liver resection was performed 
using MEDLINE (PubMed), Embase and Cochrane databases. The search terms relating to pain interventions for open liver resections included ("hepatectomy" OR "hepatectomies" OR "liver resection" OR "liver resections" OR "hepatic resection" OR "hepatic resections" OR "hepatic lobectomy" OR "hepatic lobectomies" OR "living donor hepatect") AND ("pain" OR "pains” OR "pain management" OR "postoperative pain” OR "VAS" OR "visual analog*" OR "VRS" OR "verbal rating scale*" OR "NRS" OR "numerical rating scale*" OR "pain rating” OR "epidural" OR "neuraxial” OR "intrathecal” OR "paravertebral" OR "spinal” OR "infiltration" OR "nerve block"” OR "neural block"” OR "paravertebral block"* OR "field block"* OR "transversus abdominis plane bloc"* OR "TAP block"* OR "NSAID” OR "nonsteroidal anti-inflammator"” OR "nonsteroidal anti-inflammator" OR "COX-2" OR "paracetamol” OR "acetaminophen" OR "clonidine" OR "opioid"” OR "ketamine" OR “corticosteroid"” OR "gabapentin” OR “pregabalin”).

The RCTs that reported data pooled from patients undergoing simultaneous surgical procedures were excluded as were the RCTs evaluating combinations of different perioperative interventions such as studies comparing ERAS programs to conventional care, because the variability of definitions and protocols can make practical recommendations about a particular intervention impossible. Meta-analyses that reported data on mixed surgical procedures were only included when a subanalysis on liver resection was available.

Data extraction and data analysis adhered to the PROSPECT methodology (Online supplemental file 1). ${ }^{7}$ Pain intensity scores were used as the primary outcome measure. We regarded a change of more than $10 \mathrm{~mm}$ out of $100 \mathrm{~mm}$ on the Visual Analog Scale (VAS) or more than one out of 10 on a Numerical Rating Scale (NRS) as clinically relevant. ${ }^{8}$ Secondary outcomes included cumulative 24 hours of opioid requirements, other supplementary analgesic use, opioid-related adverse events and patient-related outcome measures.

Recommendations were made according to PROSPECT methodology. ${ }^{7}$ To be recommended, the intervention must be shown to be beneficial in at least two RCTs. Additionally, to ensure clinical relevance, the relevance to current perioperative practice was assessed. Likewise, we assessed if the analgesic intervention would improve postoperative pain relief and/or outcomes when added to the 'basic analgesic regimen' or would be beneficial if this regimen is not possible or is contraindicated. Furthermore, the balance between the invasiveness of the analgesic technique and the consequences of postoperative pain, as well as the balance between the analgesic efficacy and the adverse event profile of the analgesic technique, was considered. The opioid-sparing effects of acetaminophen and non-steroidal anti-inflammatory drugs (NSAIDs) (termed as basic analgesic regimen) are well described for all surgical procedures. ${ }^{7}$ The PROSPECT group assessed if the addition of an analgesic intervention would further improve pain relief when combined with these simple, effective, non-opioid analgesics. Five questions about each recommendation were investigated: (1) Is the recommended intervention clinically relevant? (2) Does it add to the 'basic analgesic technique'?(3) Does the balance between efficacy and adverse effects allow recommendation? (4) Does the balance between invasiveness of the analgesic intervention and degree of pain after surgery allow recommendation? (5) Are the reasons for not recommending an analgesic intervention appropriate?

The proposed recommendations were sent to the PROSPECT Working Group for review and comments, and a modified Delphi approach was used. ${ }^{7}$ The Delphi approach included rounds of individual comments followed by face-to-face discussions. Each working group member responded to the questions posed to the subgroup leader, which were presented during the face-to-face meeting. This was followed by a discussion among members and a consensus was finally developed. The Delphi process resulted in complete agreement for recommendations we propose in the manuscript. Once a consensus was achieved, the lead authors drafted the final document, which was ultimately approved by the working group.

\section{RESULTS}

The Preferred Reporting Items for Systematic Reviews and MetaAnalyses flowchart demonstrating the search data is presented in figure 1. A total of 125 studies assessing analgesic interventions were identified. Ultimately, 31 RCTs and 3 systematics reviews were included for the final qualitative analysis. The characteristics of the included studies are presented in tables 1 and 2 .

\section{Preoperative interventions}

Non-steroidal anti-inflammatory drugs

Two placebo-controlled RCTs investigated the effects of preoperative and postoperative administration of parecoxib with rescue analgesia provided by intravenous patient-controlled analgesia

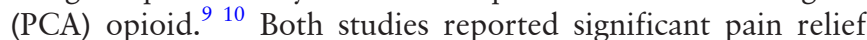
and opioid sparing with parecoxib. ${ }^{9}{ }^{10}$ Another RCT compared a combination of parecoxib with transversus abdominis plane (TAP) blocks with placebo and no TAP blocks reported significantly lower pain scores on postoperative days 1 and 2 in the study group. ${ }^{11}$ Acetaminophen, as co-analgesic, was not used in any of these studies.

\section{Intrathecal morphine}

In one RCT, intrathecal morphine $400 \mu \mathrm{g}$ reduced pain at rest for 30 hours and on coughing for 24 hours. ${ }^{12}$ Pruritus was more frequent in the intrathecal morphine group. ${ }^{12}$ Another RCT compared intrathecal morphine $400 \mu \mathrm{g}$ with a continuous ropivacaine wound infusion. ${ }^{13}$ Pain scores at rest in the intrathecal morphine group were significantly reduced only for the first 12 hours. However, pain scores on coughing were similar between groups throughout the study period. No differences in side effects were reported. ${ }^{13}$ Basic analgesics like acetaminophen and NSAIDs were not administered in both RCTs.

\section{Intraoperative interventions \\ Magnesium sulfate}

A placebo-controlled study compared a loading dose of magnesium sulfate $30 \mathrm{mg} / \mathrm{kg}$ followed by a continuous infusion of $10 \mathrm{mg} / \mathrm{kg} /$ hour, showing significantly reduced pain scores and opioid requirements. ${ }^{14}$ Basic analgesics were not administered in the control group.

\section{Alpha-2 adrenergic agonists}

A placebo-controlled RCT reported that dexmedetomidine 0.5 $\mu \mathrm{g} / \mathrm{kg}$ over $10 \mathrm{~min}$ before intubation followed by $0.3 \mu \mathrm{g} / \mathrm{kg} / \mathrm{hour}$ reduced postoperative pain scores at rest for 8 hours, and on coughing for 48 hours. $^{15}$

\section{Interfascial plane blocks}

Six RCTs focusing on the use of bilateral oblique subcostal TAP blocks with or without rectus sheath block were identified. ${ }^{16-21}$ Single-injection bilateral subcostal TAP block reduced pain at rest and with movement and reduced opioid use for 24 hours after surgery. ${ }^{16}$ Baseline analgesic consisted of acetaminophen every 6 hours. ${ }^{16}$ Another placebo-controlled RCT reported that 


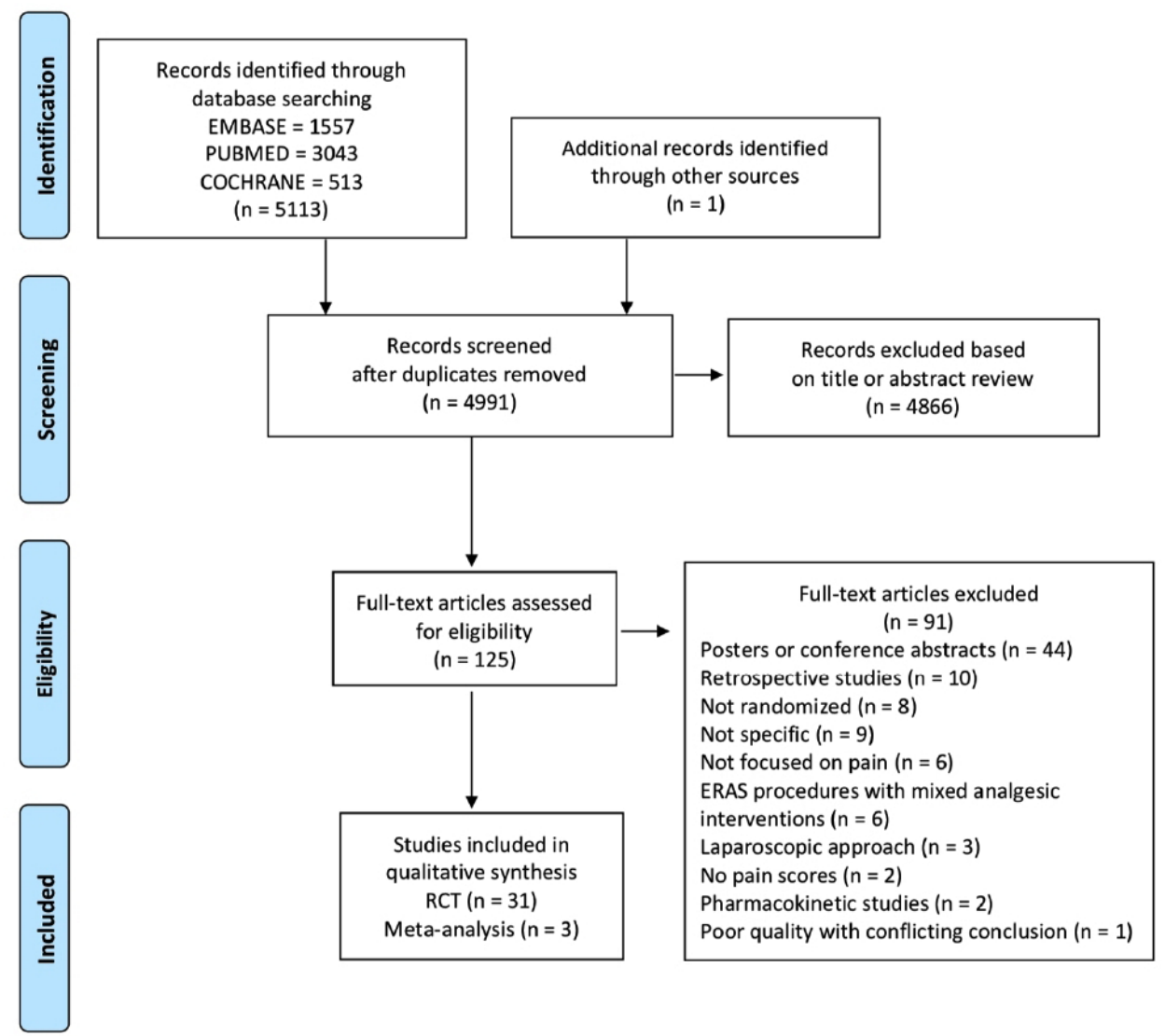

Figure 1 Preferred Reporting Items for Systematic Reviews and Meta-Analyses flow diagram. ERAS, enhanced recovery after surgery; RCT, randomized controlled trial.

single-injection bilateral oblique subcostal TAP blocks performed before the incision significantly reduced pain scores at rest at 2 and 4 hours. ${ }^{17}$ Baseline analgesia was provided with parecoxib and dexmedetomidine, with opioid as rescue analgesia. ${ }^{17}$

A placebo-controlled study reported that bilateral local anesthetic infusion via catheters placed in the medial TAP space and posterior rectus sheath both reduced pain scores at rest and with coughing and reduced opioid use for 3 days (ie, the duration of local anesthetic infusion). ${ }^{18}$ Baseline analgesic included celecoxib $200 \mathrm{mg}$ two times per day. ${ }^{18}$ Bilateral TAP blocks with bupivacaine administered before surgery followed by postoperative boluses every 8 hours via catheters placed by the surgeon provided similar pain control at rest to the control group. ${ }^{19}$ However, pain on coughing was significantly lower in the TAP group during the first three postoperative days. ${ }^{19}$ Basic analgesics (ie, acetaminophen and/or NSAIDs) were not administered. Another placebo-controlled RCT evaluated the analgesic effects of bupivacaine administered 8 hours via catheters placed by the surgeon in the TAP space and rectus sheath space. ${ }^{20}$ Pain scores and opioid use were reduced during the first two postoperative days in the intervention group. No basic analgesics were administered.

Local anesthetic infusion through catheters placed in the TAP space and the posterior rectus sheath was compared with TEA. ${ }^{21}$ The authors showed better pain control in the TEA group immediately after surgery and during the first postoperative day. After this period, differences in pain scores were less than $1 / 10$ on a NRS. It should also be noted that the TEA group showed a relatively high rate of technical failure (20\%) compared with the abdominal wall catheter group (7\%). In one patient, a deranged biochemical coagulation led to the delay of removal of the epidural catheter. Oral analgesics were mentioned but not specified. $^{21}$

An RCT investigated the analgesic effects of the quadratus lumborum (QL) block with ropivacaine infusion and boluses, if needed. Intravenous NSAIDs were administered in both groups at the end of the surgery. Pain scores were lower in the QL block group at rest, but these results were only significant at 48 hours, and the significance was lower when assessed on movement for each time interval. ${ }^{22}$

\section{Paravertebral blocks}

Compared with bilateral continuous paravertebral blocks (PVBs), TEA provided significantly lower pain scores at rest and on deep breathing up to the second postoperative day. ${ }^{23}$ Of note, basic analgesics such as intravenous ketorolac or acetaminophen were only used based on the estimated need for supplemental analgesia rather than on a scheduled basis. A mild degree of coagulopathy developed in both groups with an increase in international normalized ratio (INR) and a decrease in platelet count, which was most pronounced on the second postoperative day. Although this did not result in a delay in catheter removal in the PVB group, in the TEA group, 3 out of 41 patients had a delay in catheter removal. None of the patients in both groups developed complications related to coagulopathy. ${ }^{23}$ In a placebocontrolled study, continuous right thoracic PVB showed superior pain control at rest and with movement, as well as reduced opioid use on the first postoperative day. ${ }^{24} \mathrm{No}$ basic analgesics were used in this study. 
Table 1 Summary of key results from studies evaluating analgesic interventions that are recommended in patients undergoing open liver resection

\begin{tabular}{|c|c|c|c|c|}
\hline Study & Study design & Pain scores & Cumulative opioid dose & Basic and baseline analgesia \\
\hline \multicolumn{5}{|c|}{ Preoperative interventions } \\
\hline \multicolumn{5}{|l|}{ NSAIDs } \\
\hline Wang et $a l^{9}$ & $\begin{array}{l}\text { Procedure: open liver resection for } \\
\text { hepatocellular carcinoma. } \\
\text { Parecoxib intravenous } 40 \mathrm{mg} 30 \mathrm{~min} \\
\text { before induction followed by } 40 \mathrm{mg} \\
\text { every } 12 \text { hours for } 48 \text { hours after the } \\
\text { operation }(n=40) \text { versus placebo }(n=40) \text {. }\end{array}$ & $\begin{array}{l}\text { VAS scores lower at rest at 2, 6, } \\
12 \text { and } 24 \text { hours in the parecoxib } \\
\text { group; no difference at } 48 \text { hours. } \\
\text { VAS scores during coughing } \\
\text { significantly lower at } 2,6,12,24 \\
\text { hours in the parecoxib group, no } \\
\text { difference at } 48 \text { hours. } \\
\text { However, VAS difference at } \\
12 \text { and } 24 \text { hours is }<1 / 10 \text { (not } \\
\text { clinically relevant). }\end{array}$ & $\begin{array}{l}\text { Fentanyl intravenous-PCA } \\
\text { consumption lower in the } \\
\text { parecoxib group (reduction of } \\
\text { about } 8 \% \text { ). }\end{array}$ & $\begin{array}{l}\text { No basic analgesia and no } \\
\text { additional baseline analgesia. }\end{array}$ \\
\hline Chen et al ${ }^{10}$ & $\begin{array}{l}\text { Procedure: open liver resection for } \\
\text { hemangioma. } \\
\text { Parecoxib intravenous } 40 \mathrm{mg} \text { before } \\
\text { incision and two times per day for } 3 \\
\text { days after surgery }(\mathrm{n}=28) \text { versus placebo } \\
(\mathrm{n}=28) \text {. }\end{array}$ & $\begin{array}{l}\text { Parecoxib provided greater relief } \\
\text { than placebo following liver } \\
\text { resection with lower VAS scores } \\
\text { at } 30,42 \text { and } 54 \text { hours after } \\
\text { surgery. }\end{array}$ & $\begin{array}{l}\text { Sufentanil intravenous PCA } \\
\text { consumption at } 54 \text { hours, as } \\
\text { well as meperidine as pain } \\
\text { supplement for insufficient } \\
\text { analgesia, was lower in the } \\
\text { parecoxib group than in the } \\
\text { control group. }\end{array}$ & $\begin{array}{l}\text { No basic analgesia and no } \\
\text { additional baseline analgesia. }\end{array}$ \\
\hline Qiao et $a l^{11}$ & $\begin{array}{l}\text { Procedure: open liver resection for } \\
\text { hepatocellular carcinoma. } \\
\text { Parecoxib intravenous } 40 \mathrm{mg} 30 \mathrm{~min} \\
\text { before induction (and every } 12 \text { hours for } \\
72 \text { hours)+TAP block ( } 150 \mathrm{mg} \text { of } 0.375 \% \\
\text { ropivacaine+5 mg dexamethasone) } \\
\text { ( } \mathrm{n}=51 \text { ) versus placebo ( } \mathrm{n}=49 \text { ) before } \\
\text { anesthesia induction without TAP block. }\end{array}$ & $\begin{array}{l}\text { VAS pain scores in the } \\
\text { parecoxib+TAP group were lower } \\
\text { for POD 1-2-3 (not mentioned if } \\
\text { resting/coughing). } \\
\text { However, VAS difference between } \\
\text { groups on POD } 3 \text { is not clinically } \\
\text { relevant }(<1 / 10) \text {. }\end{array}$ & Not mentioned. & $\begin{array}{l}\text { No basic analgesia and no } \\
\text { additional baseline analgesia. }\end{array}$ \\
\hline
\end{tabular}

Intraoperative interventions

Interfascial plane blocks

Kıtllik et $a l^{16}$

Procedure: open liver resection for living VAS lower in the TAP group at 0 , donation.

VAS lower in the TAP group at 0
$2,4,6$ and 24 hours both on res

Morphine intravenous PCA

No basic analgesia and no

US-guided bilateral subcostal TAP block and on movement

$(1.5 \mathrm{mg} / \mathrm{kg}$ bupivacaine diluted with Difference in pain score always

consumption lower mean dose

over 24 hours: $40 \mathrm{mg}$ (TAP) vs 65

additional baseline analgesia.

saline to $40 \mathrm{~mL}$ volume) $(n=25)$ versus $\quad>1 / 10$.

no block $(\mathrm{n}=25)$.

$\begin{array}{ll}\text { Guo et } \mathrm{al}^{17} & \text { Procedure: open liver resection for } \\ & \text { hepatocellular carcinoma. } \\ & \text { US-guided bilateral subcostal TAP block } \\ & (40 \mathrm{~mL} \text { ropivacaine } 0.375 \%)(\mathrm{n}=35) \\ & \text { versus placebo }(\mathrm{n}=35) .\end{array}$

NRS at rest significantly lower at Intraoperative and postoperative 2 hour (median NRS $2(1-3)$ vs 2 sufentanil dose significantly

$(1-2))$ and 4 hour (median NRS 2 lower at extubation, 2 hour, 4

(1-3) vs $1(1-2)$ ) postoperatively. hour, 12 hours and 24 hours.

NRS at coughing significantly

lower at 2 hour, 4 hour, 12 hours

and 24 hours but not 5 min after extubation.

Karanicolas et $a^{18} \quad$ Procedure: open liver resection for various indications.

NRS lower POD 0 until 3

Reduced opioid requirements (removal) at rest and movement from 48 and at 72 hours.

MOTAP: Surgical placed catheters (TAP and posterior rectus abdominis space); ropivacaine $0.2 \%, 2 \times 20 \mathrm{~mL}$ at conclusion of surgery and $2 \times 5 \mathrm{~mL} /$ hour for 72 hours $(n=71)$ vs placebo $(n=82)$.

(cough), higher proportion of patients with pain score of

'moderate' (defined as NRS

score $\geq 4 / 10$ ) or higher at rest and when coughing.

No difference in reported quality of pain control/satisfaction.

$\begin{array}{ll}\text { Serag et } \text { al }^{19} & \text { Procedure: open liver resection in } \\ & \text { patients with cirrhosis (child A). } \\ & \text { US-guided bilateral posterior TAP } \\ & \text { block (bupivacaine } 0.375 \%, 15 \mathrm{~mL} \text { on } \\ & \text { both sides, before skin incision)+bolus } \\ & \text { injections of bupivacaine } 0.375 \% \text { every } 8 \\ & \text { hours via surgical inserted TAP catheter } \\ & (n=25) \text { versus no TAP block }(n=25) .\end{array}$

Similar effective pain score at rest Intraoperative fentanyl dose

(VAS score $<3$ )

on POD 1-3. comparable in both groups, less

PCA group.
Basic analgesia: parecoxib $40 \mathrm{mg}$ every 12 hours for 3 days No additional baseline analgesia.

Basic analgesia: celecoxib $200 \mathrm{mg}$ every 12 hours

No additional baseline analgesia.

No basic analgesia and no additional baseline analgesia. 
Table 1 Continued

\begin{tabular}{lll}
\hline Study & Study design & Pain scores \\
\hline Yassen et a ${ }^{20}$ & Procedure: open liver resection in & On movement and early \\
& patients with cirrhosis (child A). & ambulation, VAS score for pain \\
& Surgically placed catheters (TAP+RSP 0.2 & was reduced during the first \\
& $\mathrm{mL} / \mathrm{kg}$ of bupivacaine $0.25 \%$ three times & two postoperative days in the \\
& a day) ( $\mathrm{n}=30$ ) versus placebo (saline & TAP+RSP group. During rest, pain \\
& injection via catheter) ( $\mathrm{n}=25)$. & control was equally effective for \\
& & both groups (VAS score 3 ).
\end{tabular}

$\begin{array}{ll}\text { Bell et al }^{21} & \text { Procedure: open liver resection for } \\ & \text { various indications. } \\ & \text { Catheters in the TAP space and } \\ \text { posterior rectus sheath, bolus } 20 \mathrm{~mL} \\ \text { bupivacaine } 0,5 \% \text { followed by } 4 \mathrm{~mL} \\ \text { hour bupivacaine } 0,25 \% \text { )+intravenous } \\ \text { PCA (morphine/oxycodone based) for } \\ 60 \text { hours postoperatively }(\mathrm{n}=42) \mathrm{vs} \mathrm{EA} \\ \text { (bupivacaine } 0,15 \%+\text { fentanyl } 2 \mu \mathrm{g} / \mathrm{mL} \\ \text { 6-10 mL/hour) }(\mathrm{n}=41 \text { ). }\end{array}$

Epidural analgesia intraoperatively and postoperatively

$\begin{array}{ll}\text { Fayed et } \mathrm{al}^{35} & \text { Procedure: open liver resection for } \\ & \text { hepatocellular carcinoma in patients } \\ & \text { with cirrhosis (child A). } \\ & \text { EA at T11-T12 (bupivacaine } 0.125 \%+2 \\ & \mu \mathrm{g} / \mathrm{mL} \text { fentanyl, } 6 \mathrm{~mL} / \text { hour, bolus } 3 \\ & \mathrm{~mL} \text {, lockout } 15 \mathrm{~min})(\mathrm{n}=17) \text { versus } \\ & \text { intravenous PCA ( } \mathrm{n}=17) \text { (fentanyl, bolus } \\ & 15 \mu \mathrm{g}, 10 \text { min lockout, max } 90 \mu \mathrm{g} / \mathrm{hour} \text { ). } \\ & \text { Procedure: open liver resection. } \\ & \text { ERAS program with middle thoracic } \\ & \text { EA (local anesthetics and low-dose } \\ & \text { opioid, no more details) ( } \mathrm{n}=80 \text { ) versus } \\ & \text { conventional care without epidural } \\ & \text { ( } \mathrm{n}=80)\end{array}$

Pain scores at rest similar for POD 0-3

Pain scores with coughing lower on POD 2 (difference $<1 / 10$ ) and POD 3 (difference $>1 / 10$ ) No difference in patient satisfaction.

pain scores were worse in the CWI group than in the EA group on POD 0, afternoon of POD 1 and morning of POD 2 but not afterwards. However, the only clinical relevant difference in VAS score $(>1 / 10)$ was noted on POD 0.

Cumulative opioid dose

Basic and baseline analgesia

Fentanyl consumption was No basic analgesia and no significantly lower on POD 1 and additional baseline analgesia. POD 2.

Not mentioned.

No basic analgesia and no additional baseline analgesia.
Lower pain scores in the ERAS group Significantly higher satisfaction in the ERAS group.
More sedation on POD 1 in intravenous PCA and fewer PONV in EA (1/17 vs 3/17).
No basic analgesia and no additional baseline analgesia.

\begin{tabular}{|c|c|c|c|c|}
\hline Atalan et $a l^{37}$ & $\begin{array}{l}\text { Procedure: open liver resection for living } \\
\text { donation. } \\
\text { EA ( } L 1-L 2 \text {, confirmation with } \\
\text { epiduroscopy, } 10 \mathrm{~mL} \text { bupivacaine } \\
0.25 \%+50 \mu \mathrm{g} \text { fentanyl to achieve a } \\
\text { sensorial block at T4, then starting an } \\
\text { infusion of the same solution at } 7 \mathrm{~mL} / \\
\text { hour before starting anesthesia and } \\
\text { until end of operation)+TIVA (propofol } \\
\text { only)+EA postoperatively ( } 5 \mathrm{~mL} / \\
\text { hour) ( } \mathrm{n}=33 \text { ) versus TIVA (propofol- } \\
\text { remifentanil) and postoperative tramadol } \\
\text { infusion }(0.25 \mathrm{mg} / \mathrm{kg} \text { bolus }+0.15 \mathrm{mg} / \mathrm{kg} / \\
\text { hour }(n=33 \text { ). }\end{array}$ & $\begin{array}{l}\text { Lower VAS sore at the end of } \\
\text { operation up to } 24 \text { hours. } \\
\text { Pulmonary function tests were } \\
\text { better protected with the use } \\
\text { of EA, decreased anesthesia } \\
\text { requirements (mean propofol } \\
\text { dose) and reduced atelectasis } \\
\text { score and better pain control } \\
\text { (significantly lower VAS score). } \\
\text { Total propofol dose, decrease in } \\
\text { FEV1 and VAS at end of surgery } \\
\text { were associated with atelectasis } \\
\text { score, and atelectasis score was } \\
\text { associated with LOS. }\end{array}$ & Not mentioned. & Not mentioned. \\
\hline Hausken et $a l^{38}$ & $\begin{array}{l}\text { Procedure: open liver resection for } \\
\text { colorectal metastasis. } \\
\text { EA at T8-T9 (bupivacaine } 1 \mathrm{mg} / \\
\mathrm{mL}+\text { fentanyl } 2 \mu \mathrm{g} / \mathrm{mL}+\text { epinephrine } 2 \\
\mu \mathrm{g} / \mathrm{mL} \text {, at } 5-15 \mathrm{~mL} / \text { hour Bolus } 5 \mathrm{~mL} \text {, } \\
\text { maximum of two per hour) ( } \mathrm{n}=77 \text { ) } \\
\text { vs ketobemidone intravenous PCA } \\
\text { (1 mg bolus, lockout } 8 \text { min, max } 7 \\
\text { mg/hour)+ketorolac } 30 \mathrm{mg} \text { every } \\
8 \text { hours+local wound infiltration } \\
\text { (bupivacaine } 0.5 \% 20 \mathrm{~mL} \text { or } 0.25 \% 40 \\
\mathrm{~mL} \text { ) (n=66). }\end{array}$ & $\begin{array}{l}\text { No difference in mean pain } \\
\text { scores (NRS) for PODs } 0-5 \text { (1.7 } \\
\text { (intravenous PCA) vs } 1.6 \text { (EA), } \\
\text { non-inferiority). } \\
\text { Lower pain scores (NRS) in EA } \\
\text { versus intravenous PCA on POD } \\
0 \text { and POD 1, but higher or equal } \\
\text { on PODs 2-5. } \\
\text { Significantly less patients with } \\
\text { severe pain (NRS score } \geq 4 \text { ) on } \\
\text { POD } 0 \text { in EA, no significant } \\
\text { difference afterwards. }\end{array}$ & $\begin{array}{l}\text { Intravenous PCA group } \\
\text { was associated with earlier } \\
\text { discontinuation of pump and } \\
\text { with lower consumption of MED. } \\
\text { However, both groups received } \\
\text { oral oxycodone and epidural } \\
\text { fentanyl converted to MED as if } \\
\text { intravenous fentanyl. }\end{array}$ & $\begin{array}{l}\text { Basic analgesia: Acetaminophen } 1 \\
\text { g every } 6 \text { hours. } \\
\text { Baseline analgesia: oxycodone } 10 \\
\text { mg every } 12 \text { hours from POD one } \\
\text { to POD } 2 \text {. }\end{array}$ \\
\hline
\end{tabular}




\begin{tabular}{|c|c|c|c|c|}
\hline Study & Study design & Pain scores & Cumulative opioid dose & Basic and baseline analgesia \\
\hline Li et a $\left.\right|^{40}$ & $\begin{array}{l}\text { Systematic review and meta-analysis. } \\
\text { Intravenous PCA versus EA after open } \\
\text { hepatic resection. }\end{array}$ & $\begin{array}{l}\text { Pain scores at rest at } 12 \text { hours } \\
\text { no difference, at } 24 \text { hours higher } \\
\text { pain scores in intravenous PCA } \\
\text { group (significant), at } 48 \text { hours no } \\
\text { statistical significance. } \\
\text { Pain scores at movement at } 24 \\
\text { and } 48 \text { hours: no difference. At } 2 \\
\text { and } 12 \text { hours: higher scores in the } \\
\text { intravenous PCA group (but did } \\
\text { not reach statistical significance). }\end{array}$ & & NA \\
\hline
\end{tabular}

CWI, continuous wound infiltration; EA, epidural analgesia; ERAS, enhanced recovery after surgery; FEV ${ }_{1}$, forced expiratory volume in 1 s; LOS, length of stay; MED, morphine equivalent dose; MOTAP, medial open transversus abdominis plane; NA, not applicable; NRS, Numerical Rating Scale; NSAID, non-steroidal anti-inflammatory drug; PCA, patientcontrolled analgesia; POD, postoperative day; PONV, postoperative nausea and vomiting; RSP, rectus sheath plane; TAP, transversus abdominis plane; TIVA, total intravenous anesthesia; US, ultrasound; VAS, Visual Analogue Scale.

\section{Continuous local anesthetic infusion in the surgical wound}

Four RCTs compared the analgesic effect of continuous local anesthetics infusion via wound catheters (continuous wound infiltration (CWI)) versus saline infusion and one RCT compared CWI to intravenous analgesics. Of note, the catheters were placed at different anatomical planes. A double-blind placebo-controlled RCT found that local anesthetic infusion via a subfascial catheter reduced pain intensity after 6 hours until the second postoperative day; however, the differences were not clinically significant with both groups reporting low absolute pain scores (NRS score $<3 / 10) .{ }^{25}$ There were no differences in opioid consumption either between the groups. ${ }^{25}$ Baseline analgesia included intravenous NSAIDs and acetaminophen. Another similar study found that local anesthetic infusion through a subfascial catheter reduced opioid use but did not influence pain scores. ${ }^{26}$ Basic analgesia consisted of acetaminophen and nefopam. ${ }^{26}$ Yet another placebo-controlled RCT reported that local anesthetic infusion through two catheters placed-one in the subfascial plane and the other subcutaneously-resulted in significantly lower pain scores at rest at 8 and 16 hours but no difference on pain associated with movement. ${ }^{27}$ The use of basic analgesics was not reported. CWI was associated with an accelerated recovery and discharge compared with placebo. ${ }^{27}$ In another study, CWI via two multiorifice wound catheters buried in the musculofascial layer reduced pain at rest and during spirometry and reduced opioid use from 4 to 72 hours. ${ }^{28}$

A three-arm study investigated local anesthetic infiltration of the skin and muscular layers followed by CWI, intravenous PCA fentanyl or intravenous tramadol. Compared with the intravenous tramadol group, wound infusion and intravenous PCA fentanyl groups had lower pain scores at 6, 12, 24 and 48 hours. ${ }^{29}$ Compared with intravenous PCA fentanyl, wound infusion provided superior pain relief in the first 12 hours postoperatively. The use of basic analgesic was not mentioned. ${ }^{29}$ Local anesthetic infiltration of the parietal peritoneum, fascia and subcutaneous planes improved pain control at rest and with movement for 12 hours postoperatively; however, the differences in pain scores were not clinically significant (ie, less than $1 / 10$ on the NRS). ${ }^{30}$ An opioid-sparing effect was also noted. Other analgesics were not used. ${ }^{30}$

Two RCTs compared the analgesic effect of CWI to TEA provided for 48 hours after surgery. Pain scores were similar in both the groups at rest and with movement. ${ }^{31}$ Opioid use was higher in the CWI group until the first postoperative day but higher in the TEA group afterwards. Baseline analgesia was provided with intravenous acetaminophen. Time to functional recovery (ie, independent mobilization, eating and drinking and need of intravenous fluids) was reduced in the CWI group. ${ }^{31}$ In another study, lower pain scores at rest and with movement were observed in the TEA group and opioid consumption was higher in the CWI group. ${ }^{32}$ All patients received intravenous acetaminophen if no concern for size or quality of the liver remnant existed. $^{32}$

Two meta-analyses evaluated the analgesic effects of TEA and CWI. ${ }^{33} 34$ A subgroup analysis of four RCTs ( $n=684$ patients) for open liver surgery within a larger meta-analysis found lower pain scores in the TEA group at 2 hours at rest and at 12 hours with movement. ${ }^{33}$ Another meta-analysis of three RCTs $(n=240$ patients) showed no significant difference in pain scores between the CWI and TEA groups on the first and third postoperative days. ${ }^{34}$ However, the TEA analgesia group had lower pain scores on the second day after surgery. Opioid consumption was also reduced on the first postoperative day in the TEA group. ${ }^{34}$ This meta-analysis incorrectly included a study ${ }^{21}$ comparing TEA analgesia with interfascial plane blocks (TAP and rectus sheath blocks) rather than CWI. Thus, the conclusions of this metaanalysis are questionable since it may overestimate the beneficial effect of CWI.

\section{Thoracic epidural analgesia}

Five RCTs ${ }^{35-39}$ and one meta-analysis ${ }^{40}$ compared the analgesic effect of TEA with opioid intravenous PCA. The meta-analysis that included four RCTs ( $\mathrm{n}=278$ patients) demonstrated that, compared with opioid intravenous PCA, TEA provided superior pain relief at rest and with movement at 12 and 24 hours after surgery, with no significant difference in hospital length of stay (LOS). ${ }^{40}$ Of the four RCTs included in the meta-analysis, two RCTs ${ }^{32} 35$ are also included in our review. Of note, the meta-analysis did not consider the use of basic analgesics in the included RCTs. The RCTs included in our review but not in the meta-analysis ${ }^{40}$ also reported lower pain scores with TEA. One RCT compared TEA with ketobemidone (opioid) intravenous PCA combined with intravenous NSAIDs, while both groups received acetaminophen on a scheduled basis. ${ }^{38}$ Another placebo-controlled RCT compared intraoperative TEA with sham epidural analgesia and intrathecal morphine $(500 \mu \mathrm{g})$ and fentanyl $(15 \mu \mathrm{g})$. Patients in the TEA group suffered less pain at rest and with movements, and demonstrated significantly lower opioid use. $^{39}$

\section{Interpleural analgesia}

Interpleural analgesia with levobupivacaine infusion reduced resting pain scores at 6 hours and movement-evoked pain for 24 
Table 2 Summary of key results from studies evaluating analgesic interventions that are not recommended in patients undergoing open liver resection

\begin{tabular}{|c|c|c|c|c|}
\hline Study & Study design & Pain scores & Cumulative opioid dose & Basic and baseline analgesia \\
\hline \multicolumn{5}{|c|}{ Preoperative interventions } \\
\hline \multicolumn{5}{|c|}{ Intrathecal morphine } \\
\hline Ko et $a l^{12}$ & $\begin{array}{l}\text { Procedure: open right liver resection for living } \\
\text { donation. } \\
\text { Intrathecal morphine } 400 \mu \mathrm{g} \text { single preoperative } \\
\text { injection ( } n=20 \text { ) versus no intrathecal morphine } \\
(n=20) \text {. }\end{array}$ & $\begin{array}{l}\text { Patients in the intrathecal } \\
\text { morphine group had less pain } \\
\text { at rest up to } 30 \text { hours and when } \\
\text { coughing up to } 24 \text { hours. }\end{array}$ & $\begin{array}{l}\text { Patients in intrathecal morphine group } \\
\text { showed longer time to receive the first } \\
\text { rescue meperidine ( } 45.7 \pm 23 \text { hours vs } \\
<1 \text { hour). } \\
\text { The amounts of supplementary } \\
\text { meperidine ( } 0 \text { vs } 175 \mathrm{mg} \text { ) and fentanyl } \\
\text { intravenous PCA ( } 407.2 \mu \mathrm{g} \text { vs } 594.8 \\
\mu \mathrm{g} \text { ) required were significantly less in } \\
\text { the intrathecal morphine group. } \\
\text { Cumulative consumption of } \\
\text { meperidine and fentanyl until } 72 \\
\text { hours was significantly less in the } \\
\text { intrathecal morphine group. }\end{array}$ & $\begin{array}{l}\text { No basic analgesia and no } \\
\text { additional baseline analgesia. }\end{array}$ \\
\hline Lee et $a l^{13}$ & $\begin{array}{l}\text { Procedure: open right liver resection for living } \\
\text { donation. } \\
\mathrm{CWI} \text { (bolus ropivacaine } 0.75 \% 10 \mathrm{~mL} \text { after } \\
\text { catheter placement at the end of surgery } \\
\text { followed by ropivacaine } 0.5 \% 4 \mathrm{~mL} / \text { hour for } \\
72 \text { hours) ( } \mathrm{n}=19 \text { ) versus intrathecal morphine } \\
(400 \mu \mathrm{g} \text { ) preoperative+continuous intravenous } \\
\text { fentanyl ( } 15 \mu \mathrm{g} \text { /hour) postop ( } \mathrm{n}=21 \text { ) }\end{array}$ & $\begin{array}{l}\text { During the first } 12 \text { hours, } \\
\text { VAS score at rest was } \\
\text { lower for the intrathecal } \\
\text { morphine+intravenous fentanyl } \\
\text { group. The VAS scores at rest } \\
\text { thereafter were similar between } \\
\text { the groups. } \\
\text { The VAS scores with coughing } \\
\text { were similar between the groups } \\
\text { throughout the study time } \\
\text { period. }\end{array}$ & $\begin{array}{l}\text { Rescue intravenous fentanyl } \\
\text { requirements were significantly higher } \\
\text { in the CWI group during the first } 24 \\
\text { hours after surgery, but they became } \\
\text { similar to the requirements in the } \\
\text { intrathecal morphine/intravenous } \\
\text { fentanyl group } 24-28 \text { hours and } \\
48-72 \text { hours after surgery. }\end{array}$ & $\begin{array}{l}\text { No basic analgesia and no } \\
\text { additional baseline analgesia. }\end{array}$ \\
\hline
\end{tabular}

\begin{tabular}{|c|c|c|c|c|}
\hline \multicolumn{5}{|l|}{$\mathrm{MgSO}_{4}$} \\
\hline Mahmoud et al ${ }^{14}$ & $\begin{array}{l}\text { Procedure: open liver resection for living } \\
\text { donation. } \\
\text { Intraoperative } \mathrm{MgSO}_{4} \text { infusion ( } 30 \mathrm{mg} / \mathrm{kg} \text { bolus } \\
\text { followed by } 10 \mathrm{mg} / \mathrm{kg} \text { infusion until the end } \\
\text { of surgery) in living liver donors ( } n=25 \text { ) versus } \\
\text { placebo }(n=25)\end{array}$ & $\begin{array}{l}\text { Postoperative VAS lower in the } \\
\mathrm{MgSO}_{4} \text { group (1.2 vs 3.8). }\end{array}$ & $\begin{array}{l}\text { Postoperative fentanyl intravenous } \\
\text { PCA requirement lower ( } 70 \mu \mathrm{g} / \mathrm{hour} \text { vs } \\
114 \mu \mathrm{g} / \text { hour). }\end{array}$ & $\begin{array}{l}\text { No basic analgesia and no } \\
\text { additional baseline analgesia. }\end{array}$ \\
\hline \multicolumn{5}{|l|}{ Dexmedetomidine } \\
\hline Zhang et al ${ }^{15}$ & $\begin{array}{l}\text { Procedure: open liver resection. } \\
\text { Dexmedetomidine }(0.5 \mu \mathrm{g} / \mathrm{kg} \text { loading dose, } \\
0.3 \mu \mathrm{g} / \mathrm{kg} / \text { hour during surgery) combined with } \\
\text { postoperative oxycodone+dexmedetomidine } \\
\text { intravenous PCA ( } \mathrm{n}=26) \text { versus placebo }(\mathrm{n}=26) \\
\text { during surgery, postoperative oxycodone } \\
\text { intravenous PCA alone. }\end{array}$ & $\begin{array}{l}\text { VAS scores lower in the } \\
\text { dexmedetomidine group } \\
\text { at rest at 1, } 4 \text { and } 8 \text { hours } \\
\text { postoperatively. } \\
\text { VAS scores lower in the } \\
\text { dexmedetomidine group at } \\
\text { coughing at } 24 \text { and } 48 \text { hours } \\
\text { postoperatively. }\end{array}$ & $\begin{array}{l}\text { Postoperative consumption of } \\
\text { oxycodone intravenous PCA was lower } \\
\text { in the dexmedetomidine group at } 4,8 \text {, } \\
12,24 \text { and } 48 \text { hours. } \\
\text { Also, rescue analgesics requirement } \\
\text { (parecoxib and tramadol) in PACU } \\
\text { higher in the control group ( } 34.62 \% \\
\text { vs } 11.54 \% \text { ). }\end{array}$ & $\begin{array}{l}\text { No basic analgesia and no } \\
\text { additional baseline analgesia. }\end{array}$ \\
\hline \multicolumn{5}{|l|}{ QL blocks } \\
\hline Zhu et $a l^{22}$ & $\begin{array}{l}\text { Procedure: open liver resection. } \\
\text { US-guided continuous QL block (ropivacaine } \\
0.4 \% 0.6 \mathrm{~mL} / \mathrm{kg} \text {, then a catheter is placed: } \\
\text { ropivacaine } 0.2 \% \text {, continuous infusion at } 5 \mathrm{~mL} \text { / } \\
\text { hour, bolus } 5 \mathrm{~mL}, 15 \text { min lockout, } \max 20 \mathrm{~mL} \\
\text { hour max) }(n=32 \text { ) versus no continuous QL } \\
\text { block ( } n=31 \text { ). }\end{array}$ & $\begin{array}{l}\text { Pain scores (NRS) at rest lower } \\
\text { in the QL block group but } \\
\text { only significant at } 48 \text { hours } \\
\text { postoperatively. } \\
\text { Pain scores (NRS) at movement } \\
\text { lower in the QL block group at } \\
\text { all times. }\end{array}$ & $\begin{array}{l}\text { No significant difference in the } \\
\text { postoperative self-administered } \\
\text { analgesic dose. }\end{array}$ & $\begin{array}{l}\text { Basic analgesia: flurbiprofen } \\
100 \mathrm{mg} \text { at the end of surgery. } \\
\text { No additional baseline } \\
\text { analgesia. }\end{array}$ \\
\hline \multicolumn{5}{|c|}{ Paravertebral nerve blocks } \\
\hline Schreiber et $a l^{23}$ & $\begin{array}{l}\text { Procedure: open liver resection. } \\
\text { EA ( } 5-8 \mathrm{~mL} / \text { hour ropivacaine } 0,2 \% \text {, bolus } 3 \mathrm{~mL} / \\
\text { hour) ( } \mathrm{n}=41 \text { ) versus continuous bilateral PVB } \\
\text { ( } \mathrm{n}=39)(T 7,15 \mathrm{~mL} \text { ropivacaine } 0.5 \% \text { bolus each } \\
\text { side, followed by } 7-12 \mathrm{~mL} / \text { hour ropivacaine } \\
0.2 \% \text { each side, bolus } 3 \mathrm{~mL} \text { each side/hour) } \\
\text { during } 3 \text { days for open liver resection. The } \\
\text { infusions were started after resection, before } \\
\text { emergence. }\end{array}$ & $\begin{array}{l}\text { VRS lower at rest and during } \\
\text { deep inspiration at } 24 \text { and } \\
48 \text { hours in the EA group } \\
\text { at } 48 \text { hours (not clinically } \\
\text { relevant at } 24 \text { hours, with VAS } \\
\text { difference }<1 / 10 \text { ). }\end{array}$ & $\begin{array}{l}\text { Hydromorphone intravenous PCA } \\
\text { until at least POD 3; no difference in } \\
\text { opioid administration, no difference } \\
\text { in acetaminophen, ketorolac or } \\
\text { ketamine-infusion in both groups. }\end{array}$ & $\begin{array}{l}\text { Basic analgesia: acetaminophen } \\
\text { and ketorolac. } \\
\text { Baseline analgesia: ketamine } \\
\text { infusions were used by } \\
\text { intraoperative practitioners } \\
\text { or added by the acute pain } \\
\text { service, but according to those } \\
\text { practitioners preference. }\end{array}$ \\
\hline
\end{tabular}




\section{Table 2 Continued}

\begin{tabular}{ll}
\hline Study & Study design \\
\hline Chen et $\mathrm{al}^{24}$ & Procedure: open right liver resection. \\
& Continuous right thoracic PVB (T7, ropivacaine \\
& $0.2 \% 10 \mathrm{~mL}$ bolus, $6 \mathrm{~mL} / \mathrm{hour}$ for 24 hours) \\
& $(\mathrm{n}=24)$ versus placebo $(\mathrm{n}=24)$ infusion; first \\
& bolus before emergence.
\end{tabular}

Pain scores

Pain scores (NRS) lower on rest and coughing in the PVB group for each time point but not clinically relevant (VAS difference $>1 / 10$ ) at rest at 24 hours.

\begin{tabular}{|c|c|}
\hline \multicolumn{2}{|c|}{ Wound infiltration } \\
\hline Dalmau et $a l^{25}$ & $\begin{array}{l}\text { Procedure: open liver resection. } \\
\text { CWI (ropivacaine } 0.23 \% 10 \mathrm{~mL} \text { bolus, } 5 \mathrm{~mL} / \\
\text { hour for } 48 \text { hours) }(\mathrm{n}=53) \text { versus placebo }(\mathrm{n}=46) \\
\text { infusion. }\end{array}$ \\
\hline $\begin{array}{l}\text { Peres-Bachelot } \\
\text { et }\left.a\right|^{26}\end{array}$ & $\begin{array}{l}\text { Procedure: open liver resection for liver } \\
\text { metastasis. } \\
\text { CWI with ropivacaine } 0.375 \%, 40 \mathrm{~mL} \text { bolus } \\
\text { followed by } 8 \mathrm{~mL} / \text { hour for } 96 \text { hours }(n=42 \text { ) vs } \\
\text { placebo }(n=43 \text { ) infusion. }\end{array}$ \\
\hline
\end{tabular}
after 6 hours until POD 2

\section{Xin et $a l^{27} \quad$ Procedure: open liver resection.}

CWI with ropivacaine $0.5 \%, 20 \mathrm{~mL}$ via two catheters $10 \mathrm{~min}$ before end of surgery in both groups. On arrival in PACU: ropivacaine $0.3 \% 2$ $\mathrm{mL} /$ hour per catheter ( $=4 \mathrm{~mL} /$ hour $)$ for 48 hours ( $n=20)$ vs control: saline $4 \mathrm{~mL} /$ hour for 48 hours $(\mathrm{n}=20)$

\begin{tabular}{|c|c|}
\hline Chan et $a l^{28}$ & $\begin{array}{l}\text { Procedure: open liver resection. } \\
\text { CWI with ropivacaine } 0.25 \% \text { bolus } 20 \mathrm{~mL} \text { at } \\
\text { the end of the surgery then } 4 \mathrm{~mL} / \mathrm{hour} \text { via } \\
\text { two multiorifice catheters placed within the } \\
\text { musculofascial layer before skin closure for } 68 \\
\text { hours }(n=22) \text { vs placebo }(n=22) \text {. }\end{array}$ \\
\hline Wu et $a l^{29}$ & $\begin{array}{l}\text { Procedure: open liver resection for } \\
\text { hepatocellular carcinoma. } \\
\text { CWI with ropivacaine } 0.25 \%, 50 \mathrm{~mL} \text { infiltration } \\
\text { followed by ropivacaine } 0.25 \%, 5 \mathrm{~mL} / \text { hour } \\
\text { ( } n=20 \text { ) vs fentanyl+tropisetron intravenous PCA } \\
24-30 \mu \mathrm{g} / \mathrm{hour} \text {, bolus } 6-7.5 \mu \mathrm{g} \text {, lockout } 15 \mathrm{~min} \text {, } \\
\text { for } 2 \text { days ( } \mathrm{n}=20 \text { ) versus control with tramadol } \\
\text { intravenously according to NRS ( } n=20 \text { ). }\end{array}$ \\
\hline
\end{tabular}

$\begin{array}{ll}\text { Sun et }\left.a\right|^{30} & \text { Procedure: open liver resection. } \\ & \text { Surgical wound infiltration (ropivacaine } 0.75 \% \\ & 20 \mathrm{~mL})(\mathrm{n}=26) \text { versus placebo }(n=27) .\end{array}$

Hughes et $a l^{31} \quad$ Procedure: open liver resection. Surgically placed catheters (TAP+posterior rectus abdominis space; $40 \mathrm{~mL} 0.125 \% \mathrm{~L}$ bupivacaine on closure, elastomeric reservoir $0.375 \%$ L-bupivacaine $4 \mathrm{~mL} /$ hour for 48 hours) $(n=49)$ versus EA (T8-T9, $10 \mathrm{~mL} \mathrm{L-}$ bupivacaine $+100 \mu \mathrm{g}$ fentanyl epidural loading and infusion $0.1 \%$ L-bupivacaine $+2 \mu \mathrm{g} / \mathrm{mL}$ fentanyl for 48 hours) ( $n=48$ ).

\begin{tabular}{|c|c|c|}
\hline Revie et $a l^{32}$ & $\begin{array}{l}\text { Procedure: open liver resection. } \\
\text { CWI+PCA (at the end of the surgical procedure, } \\
\text { infiltration with } 20 \mathrm{~mL} \text { L-bupivacaine } 0.25 \% \\
\text { then L-bupivacaine } 0.375 \% 4 \mathrm{~mL} / \text { hour over } 48 \\
\text { hours) ( } \mathrm{n}=33 \text { ), vs EA at T7-T8 peroperatively } \\
\text { bupivacaine } 0.1 \% 7-10 \mathrm{~mL} / \text { hour+fentanyl } 2 \mu \mathrm{g} / \\
\mathrm{mL}(\mathrm{n}=32 \text { ). }\end{array}$ & $\begin{array}{l}\text { Pain scores lower in the EP gro } \\
\text { at rest. } \\
\text { Pain scores lower in the EA } \\
\text { group with movement. } \\
\text { Median pain scores at rest in } \\
\text { both groups equally mild. }\end{array}$ \\
\hline
\end{tabular}

Cumulative opioid dose

Basic and baseline analgesia

Lower cumulative consumption of

No basic analgesia and no sufentanil $(54.3 \mu \mathrm{g} / 24$ hours vs 68.1 additional baseline analgesia. $\mu \mathrm{g} / 24$ hours).
Pain scores (NRS) were lower in the CWI group with significance but not clinically significant (VAS difference between groups<1/10). Non-significantly lower pain score (VAS) in the CWI group.
Ropivacaine group had less pain at rest at 4-72 hours and after spirometry at 4-72 hours.
16 hours.

No difference in pain score on movement.

NRS scores at 6, 12, 24 and 48 hours in both CWI and intravenous PCA groups were significantly lower than those in the control group.

NRS scores at 6 and 12 hours lower in the CWI group than those in the intravenous PCA group.

Lower VAS scores at 0,6 and 12 hours postoperative in the intervention group at rest and movement but not clinically relevant (difference in mean VAS score $<1 / 10$ at all time).

Pain scores (NRS) were not significantly different at rest nor on movement

No difference in pain score (NRS), but advantage of CWI in recovery time over EA.
Ropivacaine group had reduced mean No basic analgesia and no total morphine consumption (58 vs $86 \mathrm{mg}$ ).
No difference in morphine consumption.

Basic analgesia: dexketoprofen and acetaminophen. No additional baseline analgesia.

Less morphine consumption $(0.5$ $\mathrm{mg} / \mathrm{kg}$ less) on PODs 1 and 2, no Total median requirements of acetaminophen was reduced but no difference in total median nefopam requirements.

Lower sufentanil consumption. Despite increased use of sufentanil in the saline group, no difference in sedation score after 16 hours. additional baseline analgesia.
No basic analgesia and no
Not mentioned

PONV lower in the CWI group than in the intravenous PCA, no difference between CWI and control.
No basic analgesia and no additional baseline analgesia.
Sufentanil consumption lower at 6,12 , No basic analgesia and no 24 and 36 hours.

Intraoperative and postoperative opioids (converted to MED); opioid consumption was greater in the CWI group up to POD 1; thereafter, EA received a significantly greater amount of opioids.
Basic analgesia: acetaminophen $1 \mathrm{~g}$ every 6 hours on PODs 1 and 2 .

No additional baseline analgesia.
Opioid use greater in the CWI group as opioid PCA was routine in this group.
Basic analgesia: standardized enhanced recovery protocol; acetaminophen every 6 hours (except if concern regarding remnant liver). POD 2: addition of ibuprofen $400 \mathrm{mg}$ every 8 hours.

No additional baseline analgesia. 
Table 2 Continued

\begin{tabular}{|c|c|c|c|c|}
\hline Study & Study design & Pain scores & Cumulative opioid dose & Basic and baseline analgesia \\
\hline Li et $a \beta^{33}$ & $\begin{array}{l}\text { Meta-analysis on open abdominal surgeries } \\
\text { (subanalysis for open liver resection): EA versus } \\
\text { CWI. }\end{array}$ & $\begin{array}{l}\text { Significantly lower pain scores } \\
\text { in EA at } 2 \text { hours on rest and } \\
12 \text { hours on mobilization than } \\
\text { those in the CWI group after liver } \\
\text { surgery. }\end{array}$ & Not mentioned. & NA \\
\hline Gavriilidis et $a l^{34}$ & $\begin{array}{l}\text { Meta-analysis on open liver resection: CWI } \\
\text { versus EA. }\end{array}$ & $\begin{array}{l}\text { No statistically significant } \\
\text { difference in pain scores between } \\
\text { groups on PODs } 1 \text { and } 3 \text {, but on } \\
\text { POD 2, patients with had lower } \\
\text { pain scores. }\end{array}$ & $\begin{array}{l}\text { On POD 1, patients with EA } \\
\text { had significantly lower opioid } \\
\text { consumption. On PODs } 2 \text { and } \\
3 \text {, patients who had CWI had } \\
\text { significantly lower opioid } \\
\text { consumption. }\end{array}$ & NA \\
\hline
\end{tabular}

Epidural analgesia with local anesthetics alone, only used intraoperatively

\begin{tabular}{|c|c|c|c|c|}
\hline Mondor et $a l^{39}$ & $\begin{array}{l}\text { Procedure: open liver resection. } \\
\text { Epidural T7-T8 or T8-T9 with local anesthetics } \\
\text { without opioids (bupivacaine } 0.5 \% \text { : first bolus } \\
\text { of } 3 \mathrm{~mL} \text { followed by an infusion of } 3 \mathrm{~mL} / \text { hour } \\
\text { intraoperatively then a bolus of } 3 \mathrm{~mL} \text { at the } \\
\text { end of the surgery, before the catheter was } \\
\text { removed) ( } n=22 \text { ) vs placebo sham epidural } \\
\text { ( } n=21) \text {. }\end{array}$ & $\begin{array}{l}\text { VAS score at rest lower in the } \\
\text { epidural group. However, the } \\
\text { difference was only clinically } \\
\text { relevant at } 6,9,24 \text { and } 36 \text { hours } \\
\text { (not at } 12,18 \text { and } 48 \text { hours). } \\
\text { VAS with movements lower } \\
\text { in the epidural group and the } \\
\text { difference was clinically relevant } \\
\text { at each time interval. }\end{array}$ & $\begin{array}{l}\text { The sham group used twice as much } \\
\text { morphine as the epidural group. }\end{array}$ & $\begin{array}{l}\text { No basic analgesia. } \\
\text { Baseline analgesia: intrathecal } \\
\text { morphine } 500 \mu \mathrm{g}+\text { intrathecal } \\
\text { fentanyl } 15 \mu \mathrm{g} \text { before the } \\
\text { surgery. }\end{array}$ \\
\hline \multicolumn{5}{|c|}{ Interpleural analgesia } \\
\hline Weinberg et $a l^{41}$ & $\begin{array}{l}\text { Procedure: open liver resection. } \\
\text { Interpleural analgesia with a } 20 \mathrm{~mL} \text { loading } \\
\text { dose of L-bupivacaine } 0.5 \% \text { at the end of the } \\
\text { surgery, followed by a continuous infusion of } \\
\text { L-bupivacaine } 0.125 \%+\text { multimodal analgesia } \\
\text { ( } n=25 \text { ) vs multimodal analgesia with morphine } \\
\text { intravenous PCA ( } n=25 \text { ). }\end{array}$ & $\begin{array}{l}\text { During the first } 24 \text { hours } \\
\text { postoperatively, the only } \\
\text { significant difference in resting } \\
\text { pain scores between the groups } \\
\text { was found at } 6 \text { hours. However, } \\
\text { pain intensity using the VAS } \\
\text { score was less on movement in } \\
\text { the interpleural group compared } \\
\text { with the intravenous PCA group } \\
\text { for the first } 24 \text { postoperative } \\
\text { hours. The greatest difference } \\
\text { in VAS score on movement } \\
\text { was also found at } 6 \text { hours } \\
\text { postoperatively where the mean } \\
\text { VAS score on movement was } \\
42 \text { mm in the interpleural group } \\
\text { and } 61 \text { mm in the intravenous } \\
\text { PCA group (difference } 18 \text { mm, } \\
95 \% \text { CI } 4 \text { to } 32 \text { mm, adjusted). } \\
\text { At } 24 \text { hours postoperatively, } \\
\text { mean (SD) VAS scores during } \\
\text { movement remained lower in } \\
\text { the interpleural group compared } \\
\text { with the intravenous PCA group } \\
44 \text { ( } 22 \text { ) mm vs } 51 \text { (18) mm, } \\
\text { respectively). However, after } \\
48 \text { hours, VAS score for pain at } \\
\text { rest and during movement was } \\
\text { similar in both groups. }\end{array}$ & $\begin{array}{l}\text { At } 24 \text { hours postoperatively, } \\
\text { the cumulative mean morphine } \\
\text { consumption was similar in the } \\
\text { groups. }\end{array}$ & $\begin{array}{l}\text { Basic analgesia: acetaminophen } \\
1 \mathrm{~g} \text { every } 6 \text { hours for the first } \\
24 \text { hours. }\end{array}$ \\
\hline \multicolumn{5}{|c|}{ Postoperative interventions } \\
\hline \multicolumn{5}{|c|}{ NSAIDs started after completion of the surgery } \\
\hline Yassen et $a l^{42}$ & $\begin{array}{l}\text { Procedure: open right liver resection for living } \\
\text { donation. } \\
\text { Ketorolac } 15 \mathrm{mg} \text { over } 30 \mathrm{~min} \text { after surgery+48- } \\
\text { hour infusion ( } 60 \mathrm{mg} \text { ketorolac/ } 240 \mathrm{~mL} \\
\text { saline }=250 \mu \mathrm{g} / \mathrm{mL}, 50 \mu \mathrm{g} / \mathrm{kg} / \mathrm{hour} \text { ) }(\mathrm{n}=28) \text { vs } \\
\text { placebo (saline) over } 30 \mathrm{~min} \text { after surgery+48 } \\
\text { hour infusion ( } 240 \mathrm{~mL} \text { saline) }(\mathrm{n}=29) \text {. }\end{array}$ & $\begin{array}{l}\text { VAS pain scores were lower in } \\
\text { the ketorolac group compared } \\
\text { with the placebo group starting } \\
\text { from } 6 \text { to } 36 \text { hours. }\end{array}$ & $\begin{array}{l}\text { Daily doses of fentanyl were lower } \\
\text { in the ketorolac group at } 24 \text { and } 48 \\
\text { hours. }\end{array}$ & $\begin{array}{l}\text { No basic analgesia and no } \\
\text { additional baseline analgesia. }\end{array}$ \\
\hline
\end{tabular}

CWI, continuous wound infiltration; EA, epidural analgesia; MED, morphine equivalent dose; MgSO ${ }_{4}$ magnesium sulfate; NA, not applicable; NRS, Numerical Rating Scale; NSAID, non-steroidal anti-inflammatory drug; PACU, postoperative care unit; PCA, patient-controlled analgesia; POD, postoperative day; PONV, postoperative nausea and vomiting; PVB, paravertebral block; QL, quadratus lumborum; TAP, transversus abdominis plane; US, ultrasound; VAS, Visual Analog Scale; VRS, Verbal Rating Scale. 
hours after surgery. ${ }^{41}$ Baseline analgesia included acetaminophen in both groups. ${ }^{41}$

\section{Postoperative interventions}

A placebo-controlled RCT evaluated the analgesic effects of intravenous ketorolac initiated postoperatively for 48 hours, and found lower pain scores and an opioid-sparing effect from 6 until 36 hours after surgery. ${ }^{42}$

\section{DISCUSSION}

This review aimed to synthesize the available evidence on procedure-specific pain management after open liver resection. We found analgesic efficacy for NSAIDs as basic analgesics administered preoperatively or intraoperatively and then continued postoperatively on the 'round-the-clock' or scheduled basis. No study investigated the analgesic efficacy of acetaminophen in liver resection, although given its relative safe profile and the few side effects, it is considered as basic (ie, first-line) analgesic according to the PROSPECT methodology. ${ }^{7}$ There is a concern of potential toxicity of acetaminophen due to possible impaired hepatic metabolism after liver resection. Nevertheless, acetaminophen was used as basic analgesic in several RCTs included in this review. A prospective case-control study investigated the glutathione and urinary acetaminophen metabolite levels after liver resection when acetaminophen was administered in a dose of $1 \mathrm{~g}$ four times a day. ${ }^{43}$ Residual liver volume was inversely correlated with postoperative urinary metabolite levels; however, no glutathione deficiency occurred. ${ }^{43}$ The risk factors for hepatotoxicity that should be considered before using acetaminophen include liver disease, age, malnutrition and intraoperative liver ischemia. The altered pharmacokinetics in patients with liver disease or after major liver resections might influence the acetaminophen dose. ${ }^{44}$ Overall, there is a low risk of acetaminophen toxicity after liver resection, and therefore, it is recommended as basic analgesic. Of note, the use of non-opioid analgesics is important in patients undergoing liver resection because it may influence opioid pharmacokinetics and thus may lead to opioid overdose. ${ }^{45}$

In addition to basic analgesics (ie, acetaminophen and NSAIDs), regional analgesic techniques such as TEA and subcostal TAP blocks were also found to be effective. Several studies confirmed the analgesic efficacy of TEA typically administered in the postoperative period, particularly during coughing and deep breathing. The limitations with TEA in patients undergoing liver resection include concerns of epidural hematoma and subsequent catastrophic neurological injuries or unplanned delays in postoperative removal of the epidural catheter due to coagulopathy and the avoidance of intraoperative use due to the potential hemodynamic effects of vascular clamping, as well as the concerns of delaying patient mobilization in the context of ERAS pathways. In fact, a large $(n=68028)$ retrospective analysis of an administrative database found that the use of TEA for major liver resection is very low (approximately 6\%). ${ }^{46}$ The propensity-matching technique showed that TEA did not seem to influence the incidence of postoperative complications, although it was associated with an increased use of blood transfusions and a longer hospital LOS in this particular population who had undergone major liver resection. ${ }^{46}$

The risk of spinal hematoma after epidural analgesia remains a matter of debate. ${ }^{47} 48$ After liver resection, coagulation disorders may develop, leading to concerns regarding the safety of removing the epidural catheter. ${ }^{49}$ The most important identified factors to predict hemostatic alterations are the preoperative liver dysfunction, the Model for End-Stage Liver Disease score, and the extent and mass of resected liver tissue. ${ }^{6}$ Nevertheless, we note that one RCT investigating TEA $^{35}$ was carried out in child A cirrhotic patients who do not show an alteration in basic coagulation tests. Of note, in patients with liver disease, an elevated INR does not necessarily predict an increased risk of bleeding. Indeed, the complex interplay of fluctuating procoagulants and anticoagulants leads often and paradoxically to a prothrombotic state. ${ }^{50}$ Nevertheless, caution should be exercised and the benefits versus harm must be carefully evaluated in this particular population. Yet, for a large number of hepatic resections and especially in the case of living donation or resection of metastases in healthy patients, TEA seems safe. ${ }^{50}$

Another concern of TEA includes delayed ambulation due to orthostatic hypotension or cumbersome equipment. However, some evidence suggests that TEA can be integrated into ERAS pathways, and its effects on attenuating the stress response to surgery and reducing postoperative pain may outweigh the other limitations. ${ }^{50}$ A recent study reported reduced risk of respiratory complications and shorter hospital LOS in patients receiving TEA. ${ }^{51}$ Furthermore, TEA allows opioid-sparing and improves gastrointestinal function. ${ }^{52}$ Also, TEA may reduce intraoperative blood loss, ${ }^{54}$ given the associated sympathetic blockade and vasodilatation which may reduce central venous pressure. ${ }^{50}$ Nevertheless, in order to attain enhanced recovery with TEA, it is imperative that the level of insertion of the epidural catheter (mid-thoracic) and the doses of local anesthetics must be carefully chosen so as to adequately cover the surgical incision site without causing motor blockade. ${ }^{50}$ Thus, the benefits of TEA may be achieved when used intraoperatively as well as postoperatively, as practiced in five included RCTs. ${ }^{21}$ 35-38

Interfascial plane blocks (eg, subcostal TAP blocks, QL blocks and erector spinae blocks) administered as single shot injection or as continuous local anesthetic infusion have been shown to be efficacious in several RCTs. Most of the studies of interfascial plane blocks related to subcostal TAP blocks with or without rectus sheath block, while only one study investigated QL blocks. QL blocks are gaining more attention recently and have been validated in numerous abdominal surgeries. ${ }^{55}$ A recent meta-analysis reported the superiority of QL blocks over TAP blocks, ${ }^{56}$ but head-to-head comparison between these two techniques in liver resection is lacking. Newer ultrasound-guided interfascial plane blocks (eg, erector spinae plane blocks) that provide abdominal wall analgesia are increasingly being developed ${ }^{57}$; however, more procedure-specific evidence is necessary before they can be recommended. Therefore, at least for now, only subcostal TAP blocks should be considered. To cover the entire surgical incision, these TAP blocks should be performed bilaterally and local anesthetics should be distributed in a subcostal and lateral approach. Since there are no studies comparing the continuous infusion of local anesthetics via catheters placed in the TAP space to a single-shot infiltration, we cannot give preference to one or the other technique.

With interfascial plane blocks, especially with continuous infusion technique, typically larger total volumes of local anesthetic are used. Given the fact that all of the currently used local anesthetics are metabolized by the liver and are highly protein bound, the possible effects of liver disease and liver surgery should be taken into account. In a double-blinded, randomized, placebocontrolled trial, the authors developed a pharmacokinetic model for ropivacaine after TAP blocks in patients undergoing hepatectomy. ${ }^{58}$ Interestingly, although the free ropivacaine clearance decreased by $53 \%$ when three or more liver segments were resected, toxic concentration threshold was never exceeded. 
Box 1 Analgesic interventions that are recommended

for pain management in patients undergoing open liver resection

Preoperative/intraoperative

- Acetaminophen.

- Non-steroidal anti-inflammatory drugs (NSAIDs).

- Thoracic epidural analgesia.

- Subcostal transversus abdominis plane blocks (single shot and/or continuous local anesthetic infusion).

Postoperative

- Acetaminophen and NSAIDs.

- Catheter-based regional analgesia technique chosen in the preoperative/intraoperative period.

Given the low extraction ratio for ropivacaine, altered metabolic function and protein binding after liver surgery appears to be more important than reduction of liver blood flow. The authors showed a higher total concentration of ropivacaine on the second postoperative day; however, the unbound ropivacaine concentration remained in the same range or was lower on the second postoperative day when more or less than three segments were resected, respectively. Although direct measurements of $\alpha_{1}$ acid glycoprotein were not performed, the increase in binding site concentration can be explained by a postoperative increase in this specific protein, which is the most important binding protein for local anesthetics. Since toxicity correlates with the unbound rather than the total local anesthetic concentration, these findings suggest that classical dosing of local anesthetics, even after major liver surgery, seems safe. Of note, the authors used a weight-based dosing regime in which a dose ropivacaine of $3 \mathrm{mg} / \mathrm{kg}$ was administered as a bolus every 12 hours for 48 hours via a catheter in the TAP space. Although the absolute quantity of infused ropivacaine is in the same range of the doses of ropivacaine in the TAP blocks evaluated in the studies in our review, the dosing regime is fundamentally different (bolus vs continuous infusion), thus potentially limiting the generalizability of these results. Apart from ropivacaine, many authors in the studies in this review used levobupivacaine as a long-acting local anesthetic. Studies investigating the pharmacokinetic profile of this specific local anesthetic in liver surgery are currently lacking. Although the distribution and elimination profile of ropivacaine and levobupivacaine are comparable, further research is necessary to confirm adequate dosing of long-acting local anesthetics

Table 3 Analgesic interventions that are not recommended for pain management in patients undergoing open liver resection

\begin{tabular}{ll}
\hline Intervention & Reason for not recommending \\
\hline Ketamine & Lack of procedure-specific evidence \\
\hline Gabapentinoids & Lack of procedure-specific evidence \\
\hline Intravenous lidocaine & Lack of procedure-specific evidence \\
\hline Dexamethasone & Lack of procedure-specific evidence \\
\hline Intraoperative use of dexmedetomidine & Limited procedure-specific evidence \\
\hline Intraoperative use of magnesium sulfate & Limited procedure-specific evidence \\
\hline Intrathecal morphine & Limited procedure-specific evidence \\
\hline Quadratus lumborum block & Limited procedure-specific evidence \\
\hline Continuous wound infiltration & Limited procedure-specific evidence \\
\hline Continuous paravertebral nerve block & Limited procedure-specific evidence \\
Postoperative intrapleural local anesthetics & Limited procedure-specific evidence \\
\hline
\end{tabular}

in liver surgery. Of note, local anesthetic toxicity occurred in none of the RCTs.

Of course, the choice of TEA versus interfascial plane blocks would depend on the potential concerns with TEA as described previously and the anesthesiologists' familiarity with the techniques.

Compared with placebo, surgical wound infiltration only demonstrated analgesic effects in the absence of basic analgesia (ie, acetaminophen and NSAIDs). Furthermore, in an RCT lacking basic analgesia, ${ }^{27}$ the analgesic effect of the continuous infusion of local anesthetics was only demonstrated during the first sixteen postoperative hours. Therefore, we do not recommend routine use of CWI; however, it may be considered as a second-line regional analgesic technique, when TEA and interfascial plane blocks (ie, subcostal TAP blocks) are not possible. Of note, it is critical to recognize that, depending on the mass of liver resected, the pharmacokinetic characteristics of local anesthetics may be impaired, which may increase the potential for systemic local anesthetic toxicity. Specific studies investigating the pharmacokinetics of CWI after liver surgery are currently lacking.

Two RCTs reported reduced pain with intrathecal morphine. One RCT compared intrathecal morphine with no treatment, ${ }^{12}$ while the other RCT compared its use with continuous local anesthetic wound infusion. ${ }^{13}$ It should be noted that the dose of morphine used in both RCTs was high (ie, $400 \mu \mathrm{g}$ ), which increases the risk of adverse events such as pruritus and respiratory depression. Also, the RCTs of intrathecal morphine did not use basic analgesics. Taken together, intrathecal morphine could not be recommended. There was insufficient procedure-specific evidence to support the use of magnesium and dexmedetomidine since only one included RCT investigated each intervention. Similarly, there was insufficient evidence for PVBs and interpleural analgesia. There was lack of evidence of gabapentinoids, intravenous lidocaine infusion, intravenous ketamine infusion and corticosteroids.

The limitations of this review are related to those of the included studies. There was considerable heterogeneity between studies, such as variable dosing regimens, variable methods of administration, a variable use of analgesics in the control groups, as well as variable time points of pain measurement. Many of the included studies suffered from small sample size and therefore it is hard to draw firm conclusions regarding the side-effect profile of the proposed interventions. In addition, most RCTs did not include basic analgesics (ie, acetaminophen and NSAIDs) in the control group, thus making it difficult to determine if the positive efficacy of the analgesic interventions studied would yield the same results when combined with basic analgesics. Furthermore, while the PROSPECT initiative promotes multimodal, non-opioid analgesic strategies and modern perioperative care, only few studies applied the multimodal analgesia or ERAS pathways. ${ }^{7}$ Future adequately powered studies should assess analgesic interventions in comparison with basic analgesics, as well as assess side effects of analgesic interventions, and it would be optimal if the role of analgesic interventions was assessed in the context of ERAS programs.

In recent years, minimally invasive approaches (eg, laparoscopic approach) are increasingly being used because they are associated with reduced pain and enhanced postoperative recovery. In carrying out this review, we also initially assessed the publications relating to minimally invasive approaches such as laparoscopic approach. Unfortunately, there were only a few (ie, three RCTs) publications investigating these surgical approaches and meeting the inclusion criteria, which are too few to draw 
any relevant conclusions. Nevertheless, similar to other surgical procedures ${ }^{59}$ performed through laparoscopic approaches, basic analgesics (eg, acetaminophen and NSAIDs) and infiltration of surgical incision or interfascial plane blocks may be adequate. In contrast, although TEA provides excellent pain relief after 'open' liver resection, its role in laparoscopic approach is questionable.

In summary, this review identified an analgesic regimen for optimal pain management after open liver resection, which is listed in box 1. We suggest perioperative pain management for liver resection to include, unless contraindicated, acetaminophen and an NSAID administered either preoperatively or intraoperatively and continued postoperatively. In the absence of contraindications, either TEA or bilateral subcostal TAP blocks are recommended. Systemic opioids should be reserved as rescue analgesics in the postoperative period. In addition, we also identified analgesic interventions that are not recommended for pain management in patients undergoing open liver resection, listed in table 3. Future high-quality studies are needed to clarify the efficacy of recommended approaches in the context of an enhanced recovery pathway.

\section{Author affiliations}

${ }^{1}$ Department of Anesthesiology, Cliniques universitaires Saint-Luc, Bruxelles, Belgium ${ }^{2}$ Department of Cardiovascular Sciences, KULeuven, Leuven, Belgium

${ }^{3}$ Anesthesia and Intensive Care Department, University of Rennes, CHU Rennes, Inserm, INRA, CIC 1414 NuMeCan, Rennes, France

${ }^{4}$ Department of Surgery, DIAKO Ev. Diakonie-Krankenhaus, Bremen, Germany

${ }^{5}$ Department of Anesthesiology, Intensive Care Medicine and Pain Therapy, University Hospital Münster, Münster, Germany

${ }^{6}$ Department of Anesthesiology and Pain Management, University of Texas,

Southwestern Medical Center, Dallas, Texas, USA

${ }^{7}$ Department of Anesthesiology, UZ Leuven, Leuven, Belgium

Contributors AD and PH conducted the article search, selected the studies based on the procedure-specific postoperative pain management methodology, collected and organized the data, and wrote the manuscript; equally contributed and therefore shared first authorship. PL, HB, SF, EMP-Z, GJ and MVdV helped establish the guidelines based on the data presented by $\mathrm{AD}$ and $\mathrm{PH}$ and helped improve the manuscript

Funding Procedure-Specific Postoperative Pain Management (PROSPECT) is supported by an unrestricted grant from the European Society of Regional Anaesthesia and Pain Therapy. In the past, PROSPECT has received unrestricted grants from Pfizer Inc., New York, New York, USA, and Grunenthal, Aachen, Germany.

Competing interests GJ has received honoraria from Baxter and Pacira Pharmaceuticals. FB has received honoraria from Pfizer, The Medicine Company, Abbott France, Nordic Pharma France, Heron therapeutics, AMBU and Grunenthal. MVdV has received honoraria from Sintetica, Grunenthal, Vifor Pharma, MSD, Nordic Pharma, Janssen Pharmaceuticals, Heron Therapeutics and Aguettant. EP-Z has received honoraria form Mundipharma, Grunenthal, MSD, Janssen-Cilag GmbH, Fresenius Kabi and AcelRx.

Patient consent for publication Not required.

Provenance and peer review Not commissioned; externally peer reviewed.

Data availability statement All data relevant to the study are included in the article or uploaded as supplementary information. The authors declare that the data supporting the findings of this study are available within the article.

Open access This is an open access article distributed in accordance with the Creative Commons Attribution Non Commercial (CC BY-NC 4.0) license, which permits others to distribute, remix, adapt, build upon this work non-commercially, and license their derivative works on different terms, provided the original work is properly cited, an indication of whether changes were made, and the use is noncommercial. See: http://creativecommons.org/licenses/by-nc/4.0/.

\section{ORCID iD}

Audrey Dieu http://orcid.org/0000-0002-6026-1734

1 Day RW, Aloia TA. Enhanced recovery in liver surgery. I Surg Oncol 2019;119:660-6.

2 Nadalin S, Capobianco I, Panaro F, et al. Living donor liver transplantation in Europe. Hepatobiliary Surg Nutr 2016;5:159-75.

3 Chang SB, Palavecino M, Wray CJ, et al. Modified Makuuchi incision for foregut procedures. Arch Surg 2010;145:281-4.
4 Yip VS, Dunne DFJ, Samuels S, et al. Adherence to early mobilisation: key for successful enhanced recovery after liver resection. Eur I Surg Oncol 2016;42:1561-7.

5 Joshi GP, Kehlet H. Postoperative pain management in the era of ERas: an overview. Best Pract Res Clin Anaesthesiol 2019:33:259-67.

6 Tzimas P, Prout J, Papadopoulos $\mathrm{G}$, et al. Epidural anaesthesia and analgesia for liver resection. Anaesthesia 2013:68:628-35.

7 Joshi GP, Van de Velde M, Kehlet H, et al. Development of evidence-based recommendations for procedure-specific pain management: prospect methodology. Anaesthesia 2019;74:1298-304

8 Myles PS, Myles DB, Galagher W, et al. Measuring acute postoperative pain using the visual analog scale: the minimal clinically important difference and patient acceptable symptom state. Br J Anaesth 2017:118:424-9.

9 Wang R-D, Zhu J-Y, Zhu Y, et al. Perioperative analgesia with parecoxib sodium improves postoperative pain and immune function in patients undergoing hepatectomy for hepatocellular carcinoma. J Eval Clin Pract 2020;26:992-1000.

10 Chen M-T, Jin B, Du S-D, et al. Role of a selective cyclooxygenase-2 inhibitor on pain and enhanced recovery after open hepatectomy: a randomized controlled trial. Trans/ Cancer Res 2017:6:806-14.

11 Qiao X-F, Jia W-D, Li Y-Q, et al. Effectiveness of parecoxib sodium combined with transversus abdominis plane block for pain management after hepatectomy for hepatocellular carcinoma: a prospective controlled study. Med Sci Monit 2019;25:1053-60.

12 Ko JS, Choi SJ, Gwak MS, et al. Intrathecal morphine combined with intravenous patient-controlled analgesia is an effective and safe method for immediate postoperative pain control in live liver donors. Liver Transp/ 2009;15:381-9.

13 Lee SH, Gwak MS, Choi SJ, et al. Prospective, randomized study of ropivacaine wound infusion versus intrathecal morphine with intravenous fentanyl for analgesia in living donors for liver transplantation. Liver Transp/ 2013;19:1036-45.

14 Mahmoud G, Sayed E, Eskander A, et al. Effect of intraoperative magnesium intravenous infusion on the hemodynamic changes associated with right lobe living donor hepatotomy under transesophageal Doppler monitoring-randomized controlled trial. Saudi J Anaesth 2016;10:132-7.

15 Zhang B, Wang G, Liu X. The opioid-sparing effect of perioperative dexmedetomidine combined with oxycodone infusion during open hepatectomy: a randomized controlled trial. Front Pharmacol 2017:8:1-9.

16 Kitlık A, Erdogan MA, Ozgul U, et al. Ultrasound-Guided transversus abdominis plane block for postoperative analgesia in living liver donors: a prospective, randomized, double-blinded clinical trial. J Clin Anesth 2017:37:103-7.

17 Guo J-guo, Li H-ling, Pei Q-qing, et al. The analgesic efficacy of subcostal transversus abdominis plane block with Mercedes incision. BMC Anesthesiol 2018;18:1-11.

18 Karanicolas PJ, Cleary S, McHardy P, et al. Medial open Transversus abdominis plane (MOTAP) catheters reduce opioid requirements and improve pain control following open liver resection: a multicenter, blinded, randomized controlled trial. Ann Surg 2018;268:233-40.

19 Serag Eldin M, Mahmoud F, El Hassan R, et al. Intravenous patient-controlled fentanyl with and without transversus abdominis plane block in cirrhotic patients post liver resection. Local Reg Anesth 2014;7:27-37.

20 Yassen K, Lotfy M, Miligi A, et al. Patient-Controlled analgesia with and without transverse abdominis plane and rectus sheath space block in cirrhotic patients undergoing liver resection. J Anaesthesiol Clin Pharmacol 2019;35:58-64.

21 Bell R, Ward D, Jeffery J, et al. A randomized controlled trial comparing epidural analgesia versus continuous local anesthetic infiltration via abdominal wound catheter in open liver resection. Ann Surg 2019:269:413-9.

22 Zhu Q, Li L, Yang Z, et al. Ultrasound guided continuous quadratus lumborum block hastened recovery in patients undergoing open liver resection: a randomized controlled, open-label trial. BMC Anesthesiol 2019;19:1-9.

23 Schreiber KL, Chelly JE, Lang RS, et al. Epidural versus paravertebral nerve block for postoperative analgesia in patients undergoing open liver resection: a randomized clinical trial. Reg Anesth Pain Med 2016;41:460-8.

24 Chen H, Liao Z, Fang Y, et al. Continuous right thoracic paravertebral block following bolus initiation reduced postoperative pain after right-lobe hepatectomy: a randomized, double-blind, placebo-controlled trial. Reg Anesth Pain Med 2014;39:506-12.

25 Dalmau A, Fustran N, Camprubi I, et al. Analgesia with continuous wound infusion of local anesthetic versus saline: double-blind randomized, controlled trial in hepatectomy. Am J Surg 2018;215:138-43.

26 Peres-Bachelot V, Blanc E, Oussaid N, et al. A 96-hour continuous wound infiltration with ropivacaine reduces analgesic consumption after liver resection: a randomized, double-blind, controlled trial. J Surg Oncol 2019;119:47-55.

27 Xin Y, Hong Y, Yong LZ. Efficacy of postoperative continuous wound infiltration with local anesthesia after open hepatectomy. Clin J Pain 2014;30:571-6.

28 Chan SK, Lai PB, Li PT, et al. The analgesic efficacy of continuous wound instillation with ropivacaine after open hepatic surgery. Anaesthesia 2010;65:1180-6.

29 Wu Y-F, Li X-P, Yu Y-B, et al. Postoperative local incision analgesia for acute pain treatment in patients with hepatocellular carcinoma. Rev Assoc Med Bras 2018;64:175-80 
30 Sun J-X, Bai K-Y, Liu Y-F, et al. Effect of local wound infiltration with ropivacaine on postoperative pain relief and stress response reduction after open hepatectomy. World J Gastroenterol 2017;23:6733-40.

31 Hughes MJ, Harrison EM, Peel NJ, et al. Randomized clinical trial of perioperative nerve block and continuous local anaesthetic infiltration via wound catheter versus epidural analgesia in open liver resection (liver 2 trial). Br J Surg 2015;102:1619-28.

32 Revie EJ, McKeown DW, Wilson JA, et al. Randomized clinical trial of local infiltration plus patient-controlled opiate analgesia vs. epidural analgesia following liver resection surgery. HPB 2012;14:611-8.

33 Li H, Chen R, Yang Z, et al. Comparison of the postoperative effect between epidural anesthesia and continuous wound infiltration on patients with open surgeries: a meta-analysis. J Clin Anesth 2018;51:20-31.

34 Gavriilidis P, Roberts KJ, Sutcliffe RP. Local anaesthetic infiltration via wound catheter versus epidural analgesia in open hepatectomy: a systematic review and metaanalysis of randomised controlled trials. HPB 2019;21:945-52.

35 Fayed NA, Abo El-Wafa HB, Gab-Alla NM, et al. Comparison between intravenous patient controlled analgesia and patient controlled epidural analgesia in cirrhotic patients after hepatic resection. Middle East J Anaesthesio/ 2014;22:467-76.

36 Qi S, Chen G, Cao P, et al. Safety and efficacy of enhanced recovery after surgery (ERAS) programs in patients undergoing hepatectomy: a prospective randomized controlled trial. J Clin Lab Anal 2018;32:1-8.

37 Atalan HK, Gucyetmez B, Donmez R, et al. Advantages of epidural analgesia on pulmonary functions in liver transplant donors. Transplant Proc 2017;49:1351-6.

38 Hausken J, Fretland Åsmund Avdem, Edwin B, et al. Intravenous patient-controlled analgesia versus thoracic epidural analgesia after open liver surgery: a prospective, randomized, controlled, Noninferiority trial. Ann Surg 2019;270:193-9.

39 Mondor M-E, Massicotte L, Beaulieu D, et al. Long-Lasting analgesic effects of intraoperative thoracic epidural with bupivacaine for liver resection. Reg Anesth Pain Med 2010;35:51-6.

40 Li J, Pourrahmat M-M, Vasilyeva E, et al. Efficacy and safety of patient-controlled analgesia compared with epidural analgesia after open hepatic resection: a systematic review and meta-analysis. Ann Surg 2019;270:200-8.

41 Weinberg L, Scurrah N, Parker F, et al. Interpleural analgesia for attenuation of postoperative pain after hepatic resection. Anaesthesia 2010;65:721-8.

42 Yassen AM, Sayed GE, El SG. Low dose ketorolac infusion improves postoperative analgesia combined with patient controlled fentanyl analgesia after living donor hepatectomy - randomized controlled trial. Egypt J Anaesth 2012;28:199-204.

43 Hughes MJ, Harrison EM, Jin Y, et al. Acetaminophen metabolism after liver resection: a prospective case-control study. Dig Liver Dis 2015;47:1039-46.
44 Galinski M, Delhotal-Landes B, Lockey DJ, et al. Reduction of paracetamol metabolism after hepatic resection. Pharmacology 2006;77:161-5.

45 Rudin A, Lundberg JF, Hammarlund-Udenaes M, et al. Morphine metabolism after major liver surgery. Anesth Analg 2007;104:1409-14.

46 Rosero EB, Cheng GS, Khatri KP, et al. Evaluation of epidural analgesia for open major liver resection surgery from a US inpatient sample. Proc 2014;27:305-12. doi:10.108 0/08998280.2014.11929141

47 Cook TM, Counsell D, Wildsmith JAW, et al. Major complications of central neuraxial block: report on the third national audit project of the Royal College of anaesthetists. Br J Anaesth 2009;102:179-90.

48 Moen V, Dahlgren N, Irestedt L. Severe neurological complications after central neuraxial blockades in Sweden 1990-1999. Anesthesiology 2004;101:950-9.

49 Matot I, Scheinin 0, Eid A, et al. Epidural anesthesia and analgesia in liver resection. Anesth Analg 2002;95:1179-81.

50 Agarwal V, Divatia JV. Enhanced recovery after surgery in liver resection: current concepts and controversies. Korean J Anesthesiol 2019;72:119-29.

51 Siniscalchi A, Gamberini L, Bardi T, et al. Role of epidural anesthesia in a fast track liver resection protocol for cirrhotic patients - results after three years of practice. World J Hepatol 2016;8:1097-104.

52 Lavand'homme P, De Kock M, Waterloos H. Intraoperative epidural analgesia combined with ketamine provides effective preventive analgesia in patients undergoing major digestive surgery. Anesthesiology 2005;103:813-20.

53 Kambakamba P, Slankamenac K, Tschuor C, et al. Epidural analgesia and perioperative kidney function after major liver resection. Br J Surg 2015;102:805-12.

54 Dewe G, Steyaert A, De Kock M, et al. Pain management in living related adult donor hepatectomy: feasibility of an evidence-based protocol in 100 consecutive donors. BMC Res Notes 2018;11:834.

55 Akerman M, Pejčić N, Veličković I. A review of the quadratus lumborum block and eras. Front Med 2018;5:44.

56 Liu X, Song T, Chen X, et al. Quadratus lumborum block versus transversus abdominis plane block for postoperative analgesia in patients undergoing abdominal surgeries: a systematic review and meta-analysis of randomized controlled trials. BMC Anesthesiol 2020;20:53.

57 Machi A, Joshi GP. Interfascial plane blocks. Best Pract Res Clin Anaesthesiol 2019;33:303-15.

58 Ollier E, Heritier F, Bonnet C, et al. Population pharmacokinetic model of free and tota ropivacaine after transversus abdominis plane nerve block in patients undergoing liver resection. Br J Clin Pharmacol 2015;80:67-74.

59 Joshi GP, Bonnet F, Kehlet H, et al. Evidence-Based postoperative pain management after laparoscopic colorectal surgery. Colorectal Dis 2013;15:146-55. 